\title{
Epidural Metastasis in Malignant Thymoma Mimicking Epidural Abscess Case Report and Literature Review
}

\section{Ji Yoon Kim', Young Seok Lee ${ }^{2}$, Dong Ho Kang ${ }^{2}$, Min Hye $\mathrm{Kim}^{3}$, Jeong Hee Lee ${ }^{3}$, Chul Hee Lee ${ }^{2}$, In Sung Park ${ }^{2}$}

Departments of ${ }^{1}$ Anesthesiology and Pain Medicine, ${ }^{2}$ Neurosurgery, and ${ }^{3}$ Pathology, Gyeongsang National University School of Medicine, Jinju, Korea

\section{Corresponding Author:} Young-Seok Lee

Department of Neurosurgery, Gyeongsang National University Hospital, 79 Gangnam-ro, Jinju 52727, Korea

Tel: +82-55-750-8112

Fax: +82-55-750-8737

E-mail: leeys1026@hanmail.net

Received: June 13, 2017

Revised: October 10, 2017

Accepted: November 17, 2017
Copyright ( $~ 2017$ by The Korean Spinal Neurosurgery Society

This is an open access article distributed under the terms of the Creative Commons Attribution Non-Commercial License (http://creativecommons.org/licenses/bync/4.0/) which permits unrestricted noncommercial use, distribution, and reproduction in any medium, provided the original work is properly cited.

Thymoma and thymic carcinoma are rare epithelial tumors that originate from the thymus gland. Extrathoracic metastases occur in the liver, kidney, and bone in $1 \%$ to $15 \%$ of patients. Although thymoma and thymic carcinoma exhibit highly aggressive biological behavior, spinal metastasis is rare. We describe a 78-year-old man with left wrist and grasp weakness that occurred 7 days before admission. The patient underwent thymoma surgery 7 years ago and was cured. Magnetic resonance images showed a rim-enhanced mass in the C6-7-T1 epidural space. C6-7-T1 laminectomy was performed and the mass was removed. Histological examination was performed and patient was diagnosed with metastatic thymoma. The previous reported case occurred with involvement of the vertebral body or posterior element, but our case was mostly rim-enhanced and appeared as an abscess and intradural extramedullary tumor.

Key Words: Thymoma, Thymic carcinoma, Spinal metastasis

\section{INTRODUCTION}

Thymoma and thymic carcinoma is a rare tumor originating from epithelial cells of the thymus. Metastasis occurs mainly in the local site or thoracic cavity ${ }^{2)}$. Spine metastasis was reported in 7 cases $^{3,5,6,8,10,12)}$. These cases were easily distinguished from metastasis by destroying the surrounding vertebral bone. However, our case was uniquely limited to the epidural space and invaded the intervertebral foramen.

\section{CASE REPORT}

A 78-year-old man developed weakness of the left wrist and grasp (grade 2). He experienced pain for 2 days, but there was no pain at admission. The patient was diagnosed with malignant thymic tumor with involvement of the lungs and underwent surgical resection 7 years ago. Histopathologically, malignant thymoma was diagnosed with combined thyroid B2 and B3. Therefore, additional radiotherapy was performed. The tumor did not recur and the patient was cured.

Cervical spine magnetic resonance imaging (MRI) revealed a rim-enhanced lesion compressing the cord into the C6-7-T1 epidural space and invading the C7-T1 intervertebral for amen. MRI with contrast showed low signal lesions in the vertebral bone of C7 (Fig. 1). A laboratory study was performed at admission.
White blood count, erythrocyte sedimentation rate, and C-reactive protein levels were normal.

A nearly total resection preserving nerve roots was performed via a total $\mathrm{C} 6-\mathrm{C} 7-\mathrm{T} 1$ laminectomy.

Histopathologically, the malignant thymoma that was operated on 7 years ago was composed of lobules separated by fibrous scar, and necrosis was observed in some of them. There were 2 types of tumor lobules: some lobules were mixed with lymphocytes of tumor epithelium, and some lobules were mostly tumor epithelial cells and lymphocytes were rarely observed (Fig. 2). The nuclei of tumor cells were round or ovoid, and the boundaries of cells were unclear. The nucleus was vesicular, indistinct, or distinct. Mitosis was rare. Tumor cells were positive for epithelial cell markers, including cytokeratin and epithelial membrane antigen, and negative for $\mathrm{CD} 5$ indicating $\mathrm{B} 2$ and B3 type thymoma. The tumor was invading the lungs and no lymph node metastasis was observed. Cervical lesions were accompanied by necrosis or bleeding. Tumor cells mixed with lymphocytes were observed. Tumor nuclei were round or ovoid and nonnodular (Fig. 3). Tumor cells were positive for epithelial cytokeratin and positive for PAX8, a thymic epithelial cell marker, and a patient was diagnosed with recurrent (metastatic) malignant thymoma.

We explained to the patient and patient's family about the patient's systemic condition and side effects of radiotherapy and chemotherapy. 
However, the patient and his family refused further treatment.

\section{DISCUSSION}

Thymoma and thymic carcinoma are uncommon epithelial lesions that originate from the thymus gland ${ }^{2}$. The incidence of thymomas has been estimated at 0.13 per 100,000 person in a year ${ }^{1)}$. On the basis of the appearance of epithelial cells, the World Health Organization unified classification proposed 3 histological types of thymomas (types A, B, and C), and 5 classes (medullary, mixed, lymphocytic, cortical, and epithelial) $^{13)}$. Moran and Suster" differentiated thymomas according to atypia of the neoplastic epithelial cells (type A-B2, well differentiated thymomas; type B3, atypical thymoma; type $\mathrm{C}$, thymic carcinoma). Al-
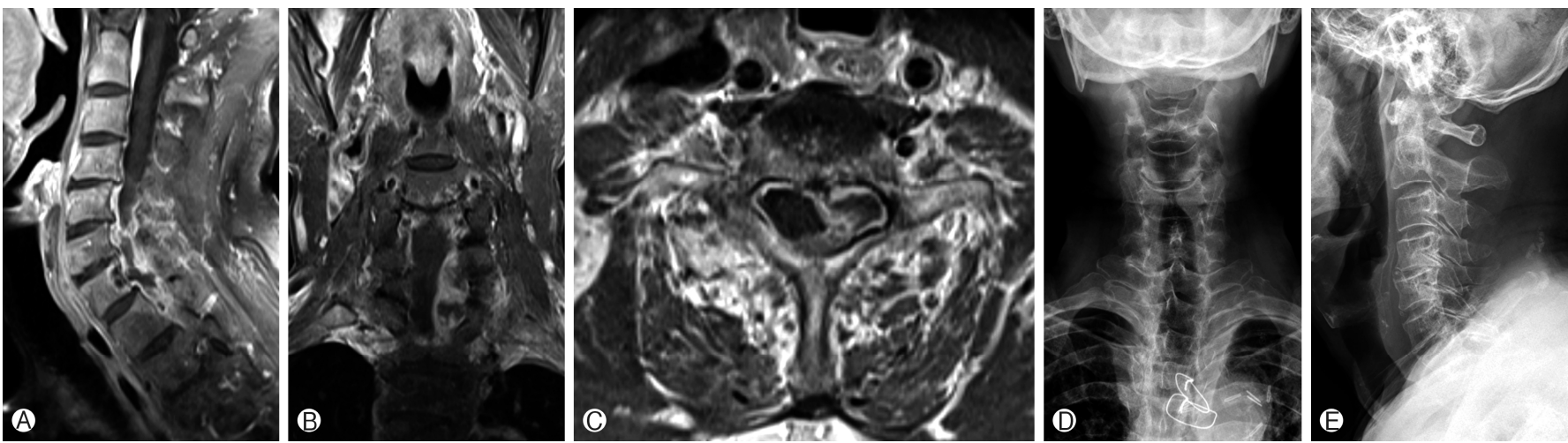

Fig. 1. Magnetic resonance imaging with contrast of the cervical spine in sagittal (A), coronal (B), and axial (C) planes shows a rim enhancement lesion in left C6-C7-T1 epidural space and low signal lesions in the vertebral bone of C7. Plane radiography in anteroposterior (D), lateral (E) views.
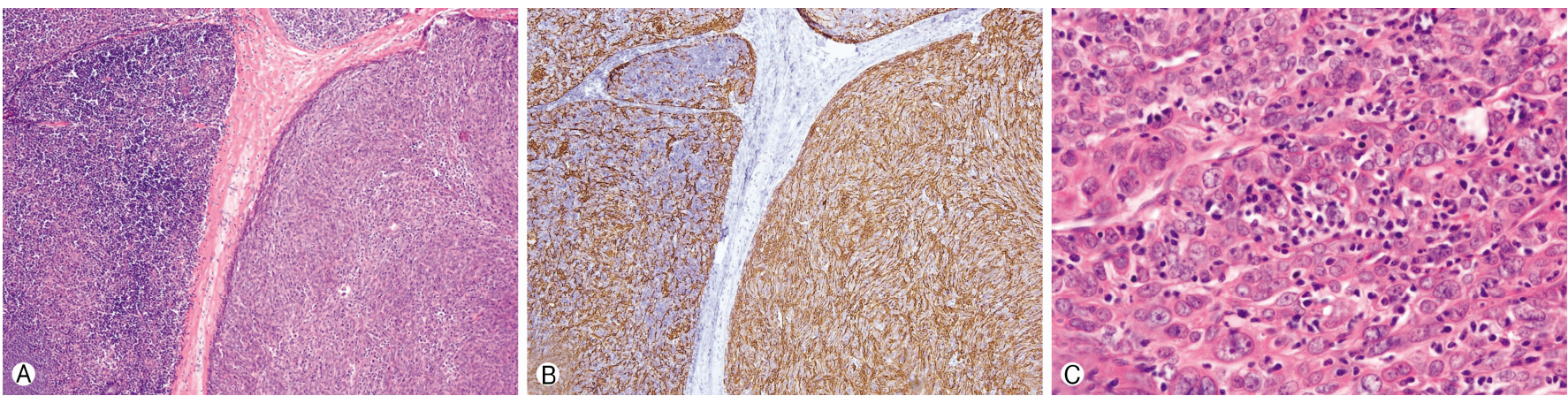

Fig. 2. Malignant thymoma. (A) The tumor shows 2 different components which are separated by fibrous septa (H\&E, $\times 100)$. (B) The left darker side shows cytokeratin positive epithelial cells admixed with lymphocytes (B2) and the right paler side shows predominant epithelial cells (B3) (cytokeratin, $\times 100)$. (C) The nucleus of tumor cells (B3) are variable sized and vesicular and some nuclei show prominent nucleoli $(\mathrm{H} \& \mathrm{E}, \times 400)$.
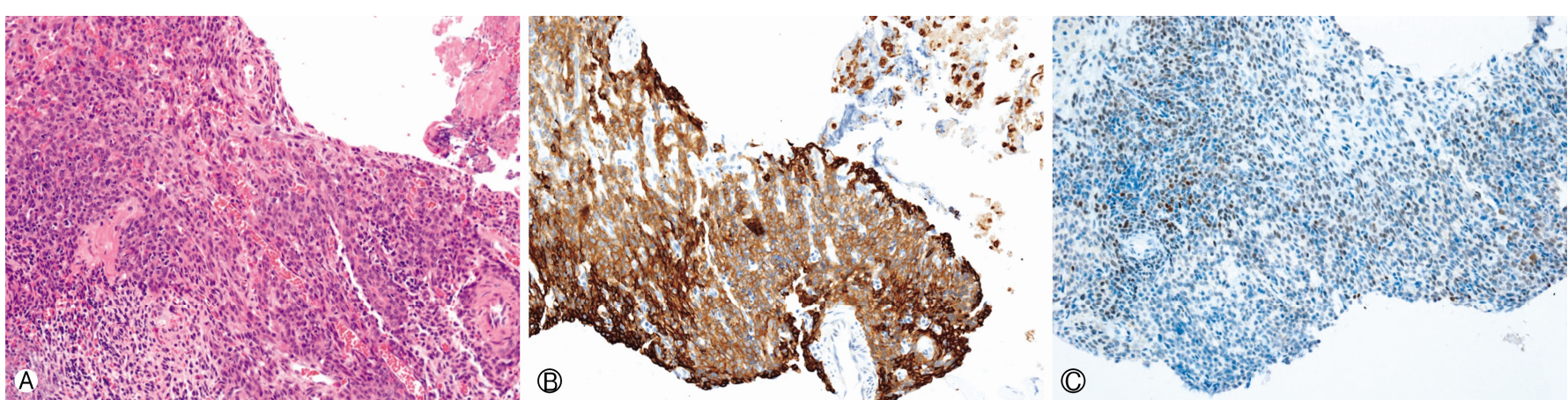

Fig. 3. Metastatic thymoma. (A) The tumor shows sheets of round cells in the background of inflammatory cells (H\&E, $\times 200)$. The tumor cells are positive for cytokeratin $(B, \times 200)$ PAX8 $(C, \times 200)$. 
Table 1. Literature review of distant spinal metastasis of thymomas

\begin{tabular}{|c|c|c|c|c|c|c|c|c|}
\hline Study & $\begin{array}{l}\text { Age } \\
\text { (yr) }\end{array}$ & Sex & $\begin{array}{l}\text { Primary } \\
\text { tumor }\end{array}$ & $\begin{array}{l}\text { Time to spinal } \\
\text { metastasis }(\mathrm{yr})\end{array}$ & Symptoms & $\begin{array}{c}\text { Location of spinal } \\
\text { Metastasis }\end{array}$ & Surgical procedures & Outcomes \\
\hline $\begin{array}{l}\text { Farin } \\
\text { et al. }\end{array}$ & 45 & Male & Thymoma & 12 & $\begin{array}{l}\text { Progressive back pain, } \\
\text { sensory disturbance in } \\
\text { toe, myasthenia gravis }\end{array}$ & $\begin{array}{l}\text { T11-12, epidural, } \\
\text { infiltration of vertebral } \\
\text { body, pedicle, } \\
\text { paraspinal muscles }\end{array}$ & $\begin{array}{l}\text { Tumor resection via } \\
\text { laminectomy T11-12, } \\
\text { partial corpectomy } \\
\text { interbody fusion }\end{array}$ & $\begin{array}{l}\text { Disease free at } \\
\text { 9-month } \\
\text { follow-up }\end{array}$ \\
\hline $\begin{array}{l}\text { Toba } \\
\text { et al. }{ }^{12)}\end{array}$ & 29 & Female & Thymoma & 4 & $\begin{array}{l}\text { Back pain, myasthenia } \\
\text { gravis }\end{array}$ & $\begin{array}{l}\text { T10-11, intervertebral } \\
\text { foramen }\end{array}$ & $\begin{array}{l}\text { Tumor resection with } \\
\text { resection the head of the } \\
10 \text { th and 11th rib }\end{array}$ & $\begin{array}{l}\text { Ne recurrence } \\
\text { for } 15 \\
\text { months }\end{array}$ \\
\hline $\begin{array}{l}\text { Liu } \\
\left.\text { et } \text { al. }^{6}\right)\end{array}$ & 57 & Male & $\begin{array}{l}\text { Thymic } \\
\text { carcinoma }\end{array}$ & $\begin{array}{l}\text { Spinal metastasis } \\
\text { was diagnosed } \\
\text { before primary } \\
\text { tumor }\end{array}$ & Paraparesis & $\begin{array}{l}\text { C4-T1, vertebral body, } \\
\text { paraspinal muscles }\end{array}$ & $\begin{array}{l}\text { Spinal cord decompression } \\
\text { via laminectomy C5-7, } \\
\text { posterior fixation C3-7 }\end{array}$ & $\begin{array}{l}\text { Died } 5 \text { months } \\
\text { later }\end{array}$ \\
\hline $\begin{array}{l}\text { Nagel } \\
\text { et al. }{ }^{10)}\end{array}$ & 67 & Male & $\begin{array}{l}\text { Carcinoid } \\
\text { tumor of } \\
\text { the thymus }\end{array}$ & 16 & Monoparesis of leg & $\begin{array}{l}\text { T3, T9, L5, epidural, } \\
\text { vertebral body, } \\
\text { paraspinal muscles }\end{array}$ & $\begin{array}{l}\text { Tuomr resection via } \\
\text { laminectomies T2-3, } \\
\text { T8-9, and L4-5 }\end{array}$ & $\begin{array}{l}\text { Died } 1 \text { year } \\
\text { later }\end{array}$ \\
\hline $\begin{array}{l}\text { Hong } \\
\text { et al. }\end{array}$ & 42 & Female & Thymoma & 8 & Back pain & L4-S1, epidural & L4, L5 hemilaminectomy & $\begin{array}{l}\text { Disease free at } \\
\text { 9-month } \\
\text { follow-up }\end{array}$ \\
\hline $\begin{array}{l}\text { Hong } \\
\text { et al. }\end{array}$ & 62 & Female & $\begin{array}{l}\text { Thymic } \\
\text { carcinoma }\end{array}$ & 13 & Segmental back pain & T9-10, epidural & $\begin{array}{l}\text { Costotransversectomy and } \\
\text { facetectomy T9-10 }\end{array}$ & $\begin{array}{l}\text { Died } 2 \text { years } \\
\text { later }\end{array}$ \\
\hline $\begin{array}{l}\text { Marotta } \\
\text { et al. } .^{8)}\end{array}$ & 46 & Male & Thymoma & $\begin{array}{l}\text { (1) } 17 \\
\text { (2) } 24\end{array}$ & $\begin{array}{l}\text { (1) Reduction of strength } \\
\text { of the left arm } \\
\text { (2) Left cervicobrachialgia, } \\
\text { reduction of strength } \\
\text { of the left arm }\end{array}$ & $\begin{array}{l}\text { (1) C5-T1, epidural } \\
\text { (2) C5-7, intradural- } \\
\text { extramedullary }\end{array}$ & $\begin{array}{l}\text { (1) Tumor resection and } \\
\text { C5-T1 stabilization } \\
\text { (2) C5-7 Tumor resection }\end{array}$ & Not reported \\
\hline $\begin{array}{l}\text { Present } \\
\text { case }\end{array}$ & 78 & Female & $\begin{array}{l}\text { Thymic } \\
\text { carcinoma }\end{array}$ & 7 & $\begin{array}{l}\text { Left wrist, grasping power } \\
\text { decrease }\end{array}$ & $\begin{array}{l}\text { C6-C7-T1, Epidural, } \\
\text { intervertebral foramen }\end{array}$ & $\begin{array}{l}\text { Laminoplasty } \mathrm{C} 6-7-\mathrm{T} 1 \text { and } \\
\text { tumor resection }\end{array}$ & $\begin{array}{l}\text { Disease free at } \\
\text { 6-month } \\
\text { follow-up }\end{array}$ \\
\hline
\end{tabular}

though thymic carcinomas are classified as type $\mathrm{C}$ in the World Health Organization classification, these tumors are not just another variant of thymoma.

In 6 cases reported previously, extradural lesions that were close to the spinal canal in MRI were compressing the dura mater and invading the paravertebral muscles $\mathrm{s}^{3,5,6,8,10,12)}$. In 1 case, intradural extramedullary metastasis was present after surgical treatment with extradural mass. After gadolinium administration, tumors showed strong enhancement. In computed tomography (CT) study, infiltrated vertebral bodies can show both as osteoplastic and osteolytic lesions. Our case was different from the case reported previously. MRI showed that the tumor was rimenhanced, and CT showed that the tumor was not invading the vertebral body (Table 1).

Local spreading occurs rapidly in thymoma but distant metastasis occurs late. The distant spinal metastasis of thymoma requires an average of 11 years (4 to 17 years) ${ }^{8)}$. Our case also developed distant metastasis after 7 years.

The 5-year survival rate of patients with distant metastasis of thymoma varied widely between $13.3 \%$ and $81 \%$ after multimodality treatment, including surgical resection of primary tumor, pleurectomy, chemotherapy, and irradiation ${ }^{14)}$. However, surgical resection is the most important treatment for thymoma metastasis. In recurrent thymoma, reoperation is more effective at increasing the 5-year survival rate than radiation and chemotherapy $^{7}$. The reoperation is aggressively recommended if it is possible to resect the lesion completely. Overall 5-year survival rates of the recurrence cases without reoperation were $36 \%$ and $51 \%$, respectively, whereas the 5 -year survival rates of the recurrence cases with reoperation were $47 \%$ and $64 \%$, respectively. Also, overall 10-year survival rates of the recurrence cases without reoperation were $17 \%$ and $43 \%$, respectively, whereas the 10-year survival rates of the recurrence cases with reoperation were $35 \%$ and $53 \%$, respectively ${ }^{4,11)}$. In metastatic thymoma, surgical treatment is also more important than other treatments.

\section{CONCLUSION}

Spinal metastasis of thymoma is rare and occurs a few years later. The previous reported case occurred with involvement of the vertebral body or posterior element, but our case was purely rim-enhanced and appeared as an abscess and intradural extramedullary tumor. In addition, if there is a spinal epidural lesion, distant metastasis due to underlying disease should be considered.

\section{CONFLICT OF INTEREST}

No potential conflict of interest relevant to this article was reported.

\section{REFERENCES}

1. Engels EA: Epidemiology of thymoma and associated malignancies. 
J Thorac Oncol 5(10 Suppl 4):S260-265, 2010

2. Engels EA, Pfeiffer RM: Malignant thymoma in the United States: demographic patterns in incidence and associations with subsequent malignancies. Int J Cancer 105:546-551, 2003

3. Farin A, Aryan HE, Abshire B: Thymoma metastatic to the extradural spine. J Clin Neurosci 12:824-827, 2005

4. Haniuda M, Kondo R, Numanami H, Makiuchi A, Machida E, Amano J: Recurrence of thymoma: clinicopathological features, re-operation, and outcome. J Surg Oncol 78:183-188, 2001

5. Hong B, Nakamura M, Hartmann C, Brandis A, Ganser A, Krauss JK: Delayed distant spinal metastasis in thymomas. Spine (Phila Pa 1976) 38:E1709-1713, 2013

6. Liu T, Qiu G, Tian Y: Thymic carcinoma with primary spine metastasis. J Clin Neurosci 18:840-842, 2011

7. Maggi G, Casadio C, Cavallo A, Cianci R, Molinatti M, Ruffini E: Thymoma: results of 241 operated cases. Ann Thorac Surg 51: 152-156, 1991

8. Marotta N, Mancarella C, Colistra D, Landi A, Dugoni DE, Delfini R: First description of cervical intradural thymoma metastasis.
World J Clin Cases 3:946-950, 2015

9. Moran CA, Suster S: Thymic carcinoma: current concepts and histologic features. Hematol Oncol Clin North Am 22:393-407, 2008

10. Nagel SJ, Hughes G, Ugokwe KT, Prayson RA, Krishnaney AA: Spinal carcinoid metastasis with dural invasion. World Neurosurg 76:478.e7-478.e11, 2011

11. Regnard JF, Zinzindohoue F, Magdeleinat P, Guibert L, Spaggiari L, Levasseur P: Results of re-resection for recurrent thymomas. Ann Thorac Surg 64:1593-1598, 1997

12. Toba H, Kondo K, Takizawa H, Tangoku A: Recurrent thymoma with a pleural dissemination invading the intervertebral foramen. Eur J Cardiothorac Surg 35:917-919, 2009

13. Travis WD, Brambilla E, Burke AP, Marx A, Nicholson AG: Introduction to the 2015 World Health Organization Classification of Tumors of the Lung, Pleura, Thymus, and Heart. J Thorac Oncol 10:1240-1242, 2015

14. Venuta F, Rendina EA, Anile M, de Giacomo T, Vitolo D, Coloni GF: Thymoma and thymic carcinoma. Gen Thorac Cardiovasc Surg 60:1-12, 2012 